\title{
Pavlos Matesis ve "Dilsizin Kızı" Eserinde Postmodernist Nitelikler, Milliyetçilik ve Öteki
}

\section{Pavlos Matesis and Post Modernist Elements, Nationalism and The Other in His Work "The Daughter"}

Mehmet Serhan ÖZEMRAH'

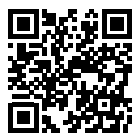

${ }^{1}$ Res. Assist., Istanbul University, Faculty of Letters, Istanbul, Turkey

\section{Corresponding author:}

Mehmet Serhan ÖZEMRAH

Istanbul Üniversitesi, Edebiyat Fakültesi,

Ordu Cad. No: 196, Çağdaş Yunan Dili ve

Edebiyatı, A Blok Kat 4, No: 29,

İstanbul, Türkiye

Phone: +90-440-0000

E-mail: mehmet.ozemrah@istanbul.edu.tr

Date of receipt: 25.10 .2017

Date of acceptance: 21.11 .2017

Citation: Özemrah, M. S. (2017). Pavlos

Matesis ve "Dilsizin kızı" eserinde

Postmodernist nitelikler, milliyetçilik ve

öteki. Litera 27(2), 91-111

http://dx.doi.org/10.26557/iulitera.364790
Öz

Çağdaş Yunan Edebiyatı, 1821'den bugüne hem kendine özgü geleneksel unsurları korumuş hem de tüm dünyada, özellikle batıda, yer alan edebi eğilimleri takip ederek otantik bir edebiyat üretmiştir. Çağdaş Yunan Edebiyatı, aynı zamanda, Yunanistan'ı etkileyen sosyal, kültürel ve tarihi olayları hem düzyazıda hem de șiirde ana unsur olarak işlemiştir. Bu tarihi olaylardan biri de tüm dünyayı etkileyen II. Dünya Savaşı ve hemen ardından Yunanistan'da yaşanan işgal, işgale direniş, kıtlık ve iç savaşı beraberinde getiren olaylar zinciridir. Bu çalışma bu olaylar ekseninde, Raraou isimli karakterin kendi hayatını anlattığı Pavlos Matesis'e ait Dilsizin Kızı isimli eseri incelenerek hazırlanmıştır. Eserde yer alan postmodernist nitelikler incelenmiş, milliyetçilik ve öteki kavramları irdelenmiștir. Bu bağlamda, tarihsel "öteki" "Türk" Çağdaş Yunan edebiyatında yerini korurken, II. Dünya Savaşı sürecinde ve sonrasında meydana gelen olaylar nedeniyle öteki kavramının değiştiği ortaya konulmuştur. Bununla birlikte milliyetçilik kavramının sorunsallaştırılarak, okuyucuyu sorgulamaya yönelttiği söylenebilir. Çağdaş Yunan Edebiyatının, kendi geleneğini devam ettirirken, dünya edebiyatındaki eğilimleri takip ettiği görülmüş. Açık bir biçimde, Matesis'in bu eserde postmodernist nitelikleri geleneksel düzyazıyla harmanlayarak özgün bir eser verdiği görülmüştür.

Anahtar Kelimeler: Pavlos Matesis, Çağdaş Yunan Edebiyatı, Postmodernist Edebiyat, Milliyetçilik, öteki

\section{ABSTRACT}

Modern Greek literature, by both preserving its traditional elements and following world literary trends, especially those from the West, has fabricated an authentic literature since 1821. Modern Greek literature has discussed social, cultural and historical events that have affected Greece, as an element in literary works as both prose and poetry. One of these historical events is World War II, this affected the whole world and launched an immediate chain of events such as the Italian occupation and resistance to the occupation, as well as the famine and civil war in Greece. This study was prepared by examining Dilsizin KIzı (The Daughter) by Pavlos Matesis, in which the protagonist Raraou tells the story of her own life in the axis of these historical events. The post-modernist elements of the work have been analyzed and the notions of nationalism and 'the other' have been scrutinized. Within this context, it is revealed that while 'Turk' preserved its place as the historical 'the other' in Modern Greek literature, the concept of the other changed as a result of the events that occurred during and after World War II. In addition, it can be said that the work prompts the reader to question the notion of nationalism by problematizing it. It has been found that Modern Greek literature, while continuing the tradition, followed trends in world literature. Matesis created a unique work by combining post-modernist elements with traditional Greek prose.

Keywords: Pavlos Matesis, Modern Greek Literature, Postmodernist Literature, Nationalism, other 


\section{EXTENDED ABSTRACT}

Modern Greek literature has been nourished by the historical, political and social phenomenon since 1821. The historical, social and political events in Greece after the Second World War prepared a literary ground for Greek writers to use their creativity. As thematic elements, the occupation of Italy in the Second World War, the resistance to this occupation, the famine and the civil war enabled the researchers to classify writers within a certain period as the 'Generation of 45 '. These writers depict not only the events during and after the Second World War in Greece, but they also reflect the literary movements and techniques across the world while continuing the Greek tradition that preceded them. In addition, while clearly reflecting on their works the dilemma brought by the period, they also convey personal and sometimes social opinions in a unique style. The work of theater and novel writer Pavlos Matesis, the subject of this study, was examined by some researchers within the Generation of 45 group. However, these studies were found to be inadequate in terms of academic point of view.

This work discusses the place and kinships of Pavlos Matesis in Modern Greek literature and the Generation of 45. Thus, it aims to provide a new and comprehensive contribution to the academic work on Pavlos Matesis. The study attempts to clarify the position and artistic style of Pavlos Matesis via his work Dilsizin Kızı (The Daughter). The story, to some extent far from epic historical narration, explains starkly how and by how much Greek society has been affected by the era of the Second World War. Using a fairly ironic style in his work, Matesis strengthens the structure of the story with rich side characters and depicts a traumatic period and its influence on Greek society. Contrary to a heroic epic, the work reflects Greek suburban culture by setting historical events in the background. However, the most genuine characteristic of the novel is not merely the story, but also the presentation of the story with the elements of post-modernist novel. The tale is told directly in a self-referential and episodic way by a woman protagonist, who turns into an anti-hero with incoherent narration. The protagonist examines the era by showing the tragicomic dilemmas, and the absurdity and the ruthlessness of life and history. Side stories in the novel also create a temporal distortion and ask specific questions of the reader, creating the technique of participation. The theater background of Matesis takes place in the story within the narration of the protagonist, which can be considered as self-referential. In addition, both the notion of nationalism and the concept of 'other' in the work were examined, 
and extent that the events in history changed the notion of 'other' was explained with the fictional examples.

The study aims to show the characteristics of post-modernist fiction and the artistic style of Pavlos Matesis in his work Dilsizin Kızı (The Daughter). Thus, it was found out that the writer and his work constitutes a paradigm of the Greek prose tradition and a post-modernist fiction that questions nationalism, history and modern age through the perception of an unstable anti-hero. 


\section{Giriş}

Batı kanonunda yerini çoktan almış Çağdaş Yunan Edebiyatı, Batıda olduğu kadar tüm dünyadaki akımları Yunan gelenekleriyle birleştirir ve Yunanistan'ı ve yunan toplumunu olduğu kadar dünyayı etkileyen olayları ve bu olayların sonuçlarını yansıtan eserler verir. İkinci dünya savaşı da tüm dünyayı olduğu kadar Yunanistan'ı da derinden etkileyen sonuçlara neden olur. Bu sonuçlar, Yunan yazarların yaratıııklarını dünyada ve batıda yer edinmiş eğilimlerle gösterebilecekleri bir zemin hazırlar. İkinci dünya savaşı dönemini ve sonrasında yaşanan, Yunanistan'ın sosyal ve kültürel olduğu kadar toplumsal hafızasını da etkileyen İtalyan işgali, ardından bu işgale direniş ve iç savaş gibi olaylar Çağdaş Yunan Edebiyatında bir dönemin ve kuşağın temaları haline gelir. İşgalin başladığı 40'ı yılların başından itibaren eser veren yazarlar 45 kuşağı yazarları olarak sınıflandırılırlar. Bu dönemde sınıflandırılan yazarlardan biri ise tiyatro geçmişi ile tanınan Pavlos Matesis'tir.

Bu çalışmaya konu olan Matesis'in Dilsizin Kızı isimli eser, edebi acıdan öteki ve milliyetçilik kavramlarını irdelerken, postmodernist roman niteliklerini içinde barındırır. Postmodernizm kavramının tanımı oldukça tartışmalı bir konudur. Postmodernist edebiyat ise bir bütün olarak postmodernizm gibi kendini "akım" olarak sınıflandırmaz. Postmodernist edebiyatın özellikle okuyucuya yaklaşımı, yapısökümcü yaklaşımları, okuyucu, eser ve yazar arasındaki iletişim gibi çeşitli nedenler ve edebi kuramlara yakınsaklığı nedeniyle bir akım olarak tanımlamak zor olabilir. (McCaffery, 1986, s. xv) Kafaoğlu - Büke (2011, s. 222-223) ise postmodernist edebiyatın; edebi eserlere daha önce var olmayan yeni bakış açıları getirdiğini, evrensellikten uzaklaşarak öznelleştiğini, yerelleştiğini ve mutlak doğruların olmadığı bir dünya arayışına sahip olduğunu ifade eder. Moran; postmodernist romanların; modernist romanın kurmaca kavramının üzerine çıkarak kurmacayı daha geniş bir estetiğe oturttuğunu belirtir (1990; 198). Bu estetiği oluşturmak içinse belirli postmodernist nitelikleri kullanılır. Bu nitelikler; Intertextuality, Irony, playfulness, black humor, Pastiche, Metafiction/ Historical Metafiction, Temporal distortion, Maximalism / Minimalism ve Magical Realism gibi tema ve teknikleri içinde barındırır (Hutcheon, 2010; Mchale, 1987; Nicol, 2009).

Bu bağlamda, Pavlos Matesis'in biyografisi araştırılmış ve ait olduğu 1945 kuşağı ile ilişkisi tartışılmıştır. Dilsizin Kızı isimli eseri, öncelikle taşıdığı postmodernist nitelikler açısından incelenmiş ve öteki ve milliyetçilik kavramı eserde yer aldığı ölçüde irdelenmiştir. 


\section{Pavlos Matesis ve Çağdaş Yunan Edebiyatında 1945 Kuşağı}

1933 yılında Mora yarımadasının Divri köyünde dünyaya gelen Pavlos Matesis, hayatının ilk on dokuz yılını Yunanistan'ın çeşitli kasabalarında yaşayarak geçirir. Daha sonra Atina'ya giderek burada tiyatro eğitimi gören yazar aynı zamanda müzik ve yabancı dil eğitimi de görür. Bir süre banka memuru olarak çalışan Matesis, tiyatro ve edebiyat için bu kariyerini bırakır. Aktörlük de yapan yazar, aktör kimliğiyle ilk olarak, Bost rumuzunu kullanan Mentis Bostantzoglou'nun "Fausta" isimli eserinde, erkek evlat rolüyle tanınır. Daha sonra Keselring'in komedisi "Arsenik ve Eski Dantel" isimli tiyatro oyununda Dr. Einstein karakterine hayat verir. Matesis, 1963 - 64 yıllarında Atina'da tiyatro eleştirisi dersleri verir. 1971 -73 yılları arasında ise dramaturg asistanı olarak Yunanistan Ulusal Tiyatrosunda çalışır. Floor Show isimli programın metin yazarlığının yanı sıra, 1974 - 76 yıllarında YENE $\Delta^{\prime} i^{1}{ }^{1}$ kanalında gösterilen iki televizyon dizisi yazar ve yönetir. Tiyatro oyun yazarı olarak sesini 1964'te sahnelenen ve

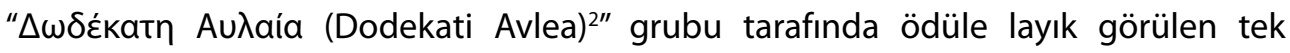

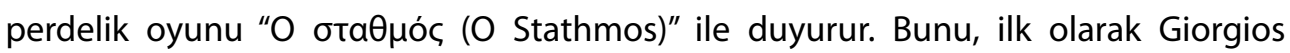
Mihalidis'in tiyatrosu Neas İonias'ta ve bundan iki sene sonra Ulusal Tiyatro'da sahnelenip tiyatro eleştirmenleri ödülüne layık görülen " $\mathrm{H} \tau \varepsilon \lambda \varepsilon \tau \eta ́$ (I teleti)" isimli eseri takip eder. Teatral üretiminin ilk dönemlerinde, Matesis, Yunan kenar mahalle kültürünün acımasız hayal kırıklıklarını sahneye taşır. Daha sonra yazarın teatral üretimi, postmodernist bir yazar olarak bilinen Samuel Beckett'in eserlerine açık bir

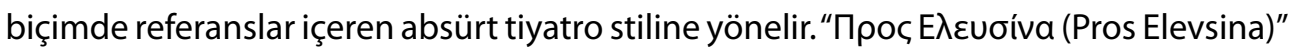

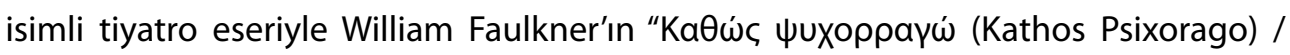
Döşeğimde Ölürken ${ }^{3}$ eserinden esinlenen Matesis, antik Yunan kültüründen yola çıkıp, halk şarkıları ve Yunan örf ve adetleri gibi unsurları kullanarak, Yunan geleneğine referanslarla hayatın yıkıcı bir ölüm kavramı üzerinden portresini aktarır.

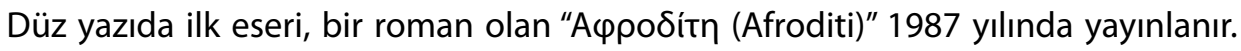

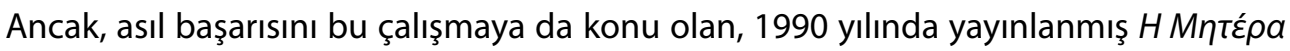

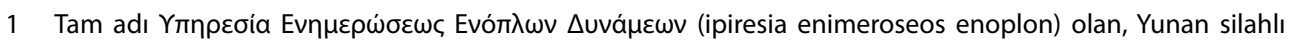
kuvvetlerine ait radyo ve televizyon kanalıdır. 1970'de ismi değiştirilen kurum, 1982'ye kadar askeri idare altında kaldıktan sonra günümüzde ERT2 kanalı olarak hizmet vermektedir.

2 1959'da Beckett, Brecht, lonesco gibi yazarlarının eserlerinden ve absürd tiyatrodan etkilenmiş, bir grup

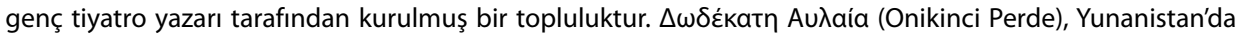
tiyatroların kapalı olduğu pazartesi günleri genç ve denenmemiş yazarların eserlerini sahneler. Topluluğun ismi, bir tiyatro topluluğunun sadece on bir oyun sergilemesine izin veren yasaya karşı bir gönderme niteliği taşır (Gassner ve Quinn, 1969, s. 399).

3 Faulkner, William (1930). As I Lay Dying /Döşeğimde Ölürken, çev. Murat Belge, İstanbul: De, 1965 


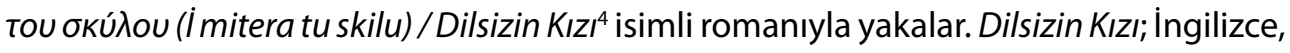
İspanyolca, İtalyanca, Almanca, Fransızca ve Türkçe olmak üzere pek çok dile çevrilir ve Quintet Publishing'in “Dünya Edebiyatından Ölmeden Önce Okunması Gereken

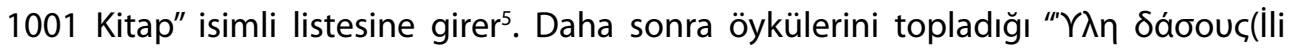

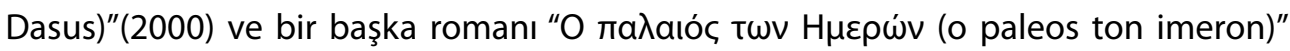
yayınlanır. Yazarın "duygusal bir roman" olarak nitelendirdiği, yine hayatın yıkıcı yönlerini aktaran eseri “Пávta kaגá (Panda Kala)", 2002'de yayınlamış ve bunu aynı

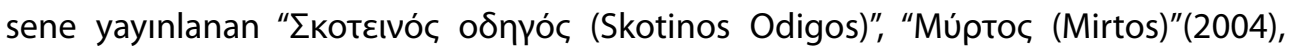
"A $\delta \delta \varepsilon \beta a \rho a ́ v ~(A l d e b a r a n) "(2007)$ ve burlesk; bir başka değişle taşlama niteliği taşıyan "Graffito" (2009) adlı eserleri takip eder. Matesis, tiyatro ve roman yazarlığı kimliğinin yanı sıra edebi ve kuramsal çeviri ile de ilgilenmiş; Mrojek, Ben Johnson, Roger Vitrac, Harold Pinter, Henrik Ibsen, Sean O' Casey, Fernando Arrabal, Joe Orton, Antonin Artaud, Margaret Atwood, William Shakespeare, Beaumarchais, Stendhal, Alain Fournier, Alba Ambert, Peter Ackroyd, William Faulkner gibi isimlerin ve Aristofanes'in

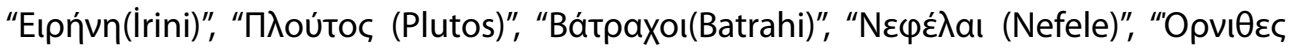

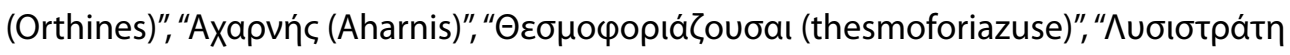
(Lisistrati)" eserlerini çağdaş Yunancaya kazandırmıştır. Beyin kanaması nedeniyle kaldırıldığı hastanede 2013 yılında vefat eder ${ }^{6}$.

Pavlos Matesis hakkında yapılan akademik çalışmalar oldukça sınırlıdır. Yazar ve eserleri hakkında doğrudan bir çalışma bulunmadığı gibi yazar, akademisyenler tarafından, genellikle, sanatsal biçim ve dönem temelinde tiyatro yazarlarının dâhil edildiği bir kategoride değerlendirilir. Örneğin Puchner, (Пoúxvep, 2004, s. 122-123) Pavlos Matesis'i, Vasilis Ziogas, Loula Anagnostaki ve Margarita Lymperaki ile birlikte, genelde, burjuvaziyi iğneleyen bir hicvi ve Yunan geleneğini eserlerinde yaratıcı unsur olarak kullanan tiyatro yazarları kategorisine dâhil eder. Bu nedenle, Matesis'in roman yazarlığından daha ziyade tiyatro yazarı kimliği, araştırmacılar ve akademisyenler tarafından ön plana çıkartıldığı söylenebilir. Ünlü Çağdaş Yunan

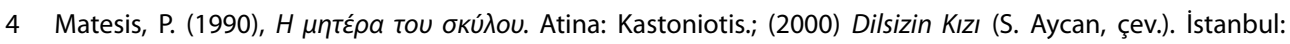
Everest Yayınları.

5 Buna rağmen Yunanistan'da sözü geçen eleştirmenler Tsaknias ve Kourtovik, esere olumlu tepkiler vermemişlerdir. Özellikle Kourtovik, eseri oldukça sıradan bulmuş ve Tsaknias'la fikir birliği yaparak, romanın tarihsel dokusunun yaşanmış olayların tasvirinde yeterli olmadığını ileri sürer (Tsaknias, 2000, s. 137-141) (Kourtovik, 1991, s. 120129). Buna rağmen roman, epik bir kahramanlık destanından çok uzak bir şekilde yaşanmış olayları sıradan insanların gözünden kurgusal bir biçimde aktarırken, bu olayları tüm çıplaklığılla tasvir eder.

6 Yazar hakkında biyografik bilgi akademik çalışmaların yetersizliği nedeniyle bağlantı adresi verilen siteden 15.01.2017 tarihinde alınmıștır.

http://www.biblionet.gr/author/12455/\%CE\%A0\%CE\%B1\%CF\%8D\%CE\%BB\%CE\%BF\%CF\%82_\% CE\%9C\%CE\%AC\%CF\%84\%CE\%B5\%CF\%83\%CE\%B9\%CF\%82 
edebiyatı tarihçileri Vitti, Politis, Dimaras ve Beaton gibi isimlerin Matesis ve eserlerine değinmeleri kronolojik olarak mümkün olmamıştır. Buna rağmen, bir başka araştırmacı Dimitris Tsiovas, Matesis'in roman yazarı kimliğine değinir. (Tziovas, 2003, s. 48) Ancak bu kimliği, tiyatro yazarlığı alanında olduğu gibi belirli bir grup içinde inceler. Tsiovas, Matesis'i ve bu çalışmaya materyal olan Dilsizin Kızı isimli eseri, genellikle kadınlar tarafından anlatılan sözlü bir tarih anlatısının arttığı dönemde epikten, anıtsallıktan, tarafsızlık arayışındaki bir anlatıdan uzaklaşan ancak, kişisel ve bölümlü bir anlatıya daha çok yönelen, Thanassis Valthinos, Nikos Houliaras gibi yazarlarla birlikte tek paragrafta inceler. Yapılan araştırmada Pavlos Matesis ve dolayısıyla yazarın romanları ile ilgili olarak doğrudan ve geniş kapsamlı bir çalışma yapılmadığı görülmüştür. Buna rağmen; yazarı ve çalışmaya konu olan eserini bir gruba ya da döneme dâhil etmemiz gerekebilir. Ancak, yazarı ve eserini, yazarın sanatsal üretime başladığı yıllar ve eserin ilk basım yılı (1990) göz önüne aldığımızda belirli bir döneme ve gruba yerleştirmek zor olabilir.

Matesis'in Dilsizin Kızı isimli eseri Yunanistan'ın yakın tarihine, İkinci Dünya savaşına ve bu dönemde yaşanan olayları sıradan insanlar üzerinden aktarır. Demirözü (Demirözü, 2015, s. 18); Yunanistan'da ikinci dünya savaşını takiben gerçekleşen işgal, direniş ve iç savaşı olarak belirtilen olguların edebiyatta, üzerinde uzlaşmaya varılamadığı yakın geçmişe ait unsurlar olduğunu, aynı zamanda bu olguların açıklanmasının güç olduğunu belirtir. Buna rağmen; işgal, direniş ve iç savaş anlatan eserler için Savaş Sonrası Edebiyat ya da 45 Kuşağı ifadelerinin kullanıldığını ekler. (Demirözü, 2015, s. 180) Matesis'in Dilsizin Kızı isimli eseri; tarihsel bağlamda, 1940'da İtalya'nın Arnavutluk üzerinden Yunanistan'ı işgal etmesi ve Yunanistan'ın bu işgale direnerek Arnavutluk'un yarısını ele geçirmesiyle başlar. Ancak daha sonra Alman ve İtalyan ordularının Yunanistan'ı işgal süreciyle devam eder. Ardından bu işgale direniş ile birlikte $\pi \varepsilon i v a$ (pina) olarak bilinen kıtlık dönemi ve iç savaşı takip eden bir olay örgüsü izleyerek geç 80'lere kadar gelir ${ }^{7}$ Bu nedenle Matesis'in Dilsizin Kızı adlı eserinin ve yazarın, gerek eserin işlediği konular gerekse olay örgüsünden yola çıkarak 1945 sonrası kuşağa ait olduğunu söyleyebiliriz. Sadece Çağdaş Yunan edebiyatında değil aynı zamanda dünya edebiyatında pek çok yazar, İkinci Dünya Savaşına ister tanıklık etmiş olsunlar ister olmasınlar oluşturdukları kurguda belirgin bir dönem olarak savaşı, savaşın öncesini ve sonrasını tema olarak ele alırlar. Ek olarak, post modernist yazarların ciddi konulara eserlerinde yer verdikleri ve bu konuları

7 Bu sonuca, her ne kadar kitabın kahramanı Raraou/Rubini gerçek yaşını açıkça söylemese de yaşıyla ilgili kullandığı ifadeler ve hikâyenin başlangıç tarihinin 1940'lar olmasından yola çıkarak varılmıştır. 
nükteli bir şekilde işlemeleri yaygındır. Buna örnek olarak Heller, Vonnegut ve Pynchon gibi yazarların İkinci Dünya Savaşını eserlerinde işlemeleri buna örnek olarak verilebilir (Sharma ve Chaudhary, 2011, s. 193). Matesis de hem Yunanistan tarihi hem de dünya tarihinde önemli izler bırakmış bu dönemi eserin kurgusunda işler. Bu döneme postmodernist yazarlar gibi nükteli bir şekilde yaklaşsa da, yaşanan olayları tüm gerçekliğiyle yansıtır. Matesis'in bu noktada eğilimi hayatın absürtlüğünü vurgulamak olarak düşünülebilir.

Dilsizin Kızl; ilk kez Edouard Dujardin'in Les Lauriers sont coupés isimli eserinde görülen fakat Yunanistan'da iç savaş sırasında (1946 - 1949) Selanik'te ortaya çıkan ve ilk temsilciğini Nikos Mbakolas'ın yaptığı, savaş sonrası dönem edebiyatının düzyazısında kullanılan bir iç monolog tekniği ve bilinç akışı tekniğiyle aktarılır. Bunun yanı sıra gerçekçi anlatım kurallarını ve birinci şahısta anlatma eğilimi gibi özgönderimsel üslup kullanan Matesis'in bu tekniği Yiorgos lannou, Hristoforos Milionis gibi yazarlarda da görülebilir. 1945 sonrası kuşağı içinde sınıflandırılan Dimitris Hatzis, Kostas Katzias, Andreas Frangias, Stratis Tsirkas, Spiros Plaskovitis gibi yazarlar, zamanın sosyal ve politik çatışmalarından etkilemiş ve sosyal olaylara ilişkin -kısmı de olsa kişisel- endişelerini eserlerine yansıtmışlardır. Matesis de benzer bir biçimde, bu çalışamaya konu olan, hikâyenin ana kahramanının anlatısından zamanın sosyal ve politik olaylarını ve yaşanmış bir tarihi oldukça ironik ve zaman zaman trajikomik bir üslupla tasvir eder. Dolayısıyla eseri ve yazarını biçimsel olarak da 45 sonrası kuşakta sınıflandırmak yanlış bir girişim olmaz. Sahinis'in ifade ettiği gibi (Sahinis, 1965, s. 11); 1940'lardan itibaren sosyal, politik, kültürel değişiklikler ve savaş bu tür eserlerin doğmasına zemin hazırlar. 1945 sonrasında ortaya çıkan modern düzyazıda, yalnızık teması, suçluluk, isyan, hayatın absürtlüğü vb. çağdaş sorunlar yaşadığımız çağın temel karakteristiği tanımlar. 1945 sonrası kuşak yazarlarında görülen politik ve tarihsel deneyimin getirdiği ortak bütünlük, öte yandan günlük yaşam, yalnızlık ve bireylerin çeşitli çıkmazları düzyazıda bu dönemin karakteristik unsurlarını oluşturur. (Milionis, 1991, s. 45) Ana kahramanın/anlatıcının biyografisi, onun kendi ağzından, Yunanistan'ın yakın geçmişine ait olaylar ekseninde ve bu olayların romandaki karakterlerin hayatlarına açık ve derin etkisi yadsınmadan tüm gerçekliğiyle anlatılır. Bu nedenle Matesis'in eserinde, insanların yabancılaşma, suçluluk, isyan vb. hislerin nedeni; dönemin insanlar üzerinde yarattığı etkiler ve tarih sahnesinde yaşanan olayların yarattığı travmatik deneyimlerle ilişkilendirilir. Dolayısıyla biçimsel olduğu kadar tematik olarak da Matesis ve eseri 1945 sonrası kuşağa sınıflandırabilir. 


\section{Dilsizin Kızı ve Postmodernist Nitelikleri}

45 kuşağı eserlerinde, diğer kuşak ve dönemlere kıyasla, rastlanan bir diğer niteliksel ayrım ise insan ilişkileri üzerinden anlatılan "hayat" kavramının trajik çıkmazlarının ironik bir anlatıyla irdelenmesidir. Pavlos Matesis'in Dilsizin Kızı eseri buna benzer bir biçimde, arka plana tarih sahnesinden olayları yerleştirerek, hayatı acımasızlığını ve absürtlüğünü sorgularken, İkinci Dünya Savaşının başlangıç yıllarından yakın tarihe kadar Yunanistan'da gerçekleşen politik, kültürel ve sosyal değişikliği ironi ve mizah unsurlarına başvurarak aktarır. Böylece tarih, Matesis'in Dilsizin Kızı isimli eserinde bir laytmotif bir başka değişle ana unsur olarak karşımıza çıkar. Ancak Matesis, bu eserinde yakın tarihi yeniden anlatırken mizah ve ironi unsurlarını bir araç olarak kullanır. Umberto Eco'nun tarihin yok edilemeyeceğini, edilirse sessizliğe neden olacağını, bu nedenle tarihin ironiyle ancak tüm gerçekliğiyle yeniden keşfinin modernizme karşı post modern bir cevap olduğunu ifade eden sözleri (Eco, 1994, s. 67-68) düşünüldüğünde, Matesis'in de bu eserinde tarihi tüm çıplaklığıyla fakat ironik bir anlatıyla yeniden keşfetmesi post modern bir unsur olarak düşünülebilir. Hutcheon ise postmodernizmin nostalji yaratmaktan çok ironiyle ilgilendiğini ve bu iki kavramın postmodernizm aracılığı ile edebi bir zeminde buluştuğunu ifade eder. (Hutcheon, 1998, s. 21) Matesis de hem geçmişi hem de ironiyi bu eserinde başarılı bir şekilde eritir. Dolayısıyla geçmişin ironiyle aktarılması post modern bir karakteristik olarak karşımıza çıkar.

Eser, Epalksis adı verilen bir taşrada başlar ve Atina'da son bulur. Matesis'in biyografisini kaynak olarak ele alındığında, taşra hayatını bildiğini ve taşrada yaşayan insanları oldukça ayrıntılı bir biçimde eserinde tasvir ettiği rahatlıkla söylenebilir. Ana kahraman Raraou'nun (Rubini Meskari) kendi ağzından aktarılan hikâye; Raraou ve annesi Asimina'nın taşradan Atina'ya doğru uzanan hayat hikâyesini anlatır. Yunanistan'ın politik, sosyal ve kültürel çalkantılar yaşadığı İkinci Dünya Savaşı süreci ve hemen ardından yaşanan olaylar ekseninde sıradan insanların dramatik hayatları natüralist bir üslup ile aktarılır. Tarihsel arka plana bakıldığında eser, İkinci Dünya Savaşı sırasında İtalya'nın Yunanistan'ı Arnavutluk üzerinden işgal etme girişimi üzerine Yunanistan'da o sırada yönetimde bulunan 
Metaksas'ın ünlü "Hayır"ıyla başlar ${ }^{8}$ ve Yunanistan'ın Güney Arnavutluk topraklarını girmesiyle devam eder. Raraou'nun babasının, İtalya'nın Yunanistan'ı işgali tehlikesine karşılık Arnavutluk cephesine gitmesi ve geri dönememesi Raraou'nun hikâyesinin ilk çarpıcı deneyimi olarak karşımıza çıkar. Ekim 1940'da İtalyanların başarısızlıkla sonuçlanan, Arnavutluk üzerinden Yunanistan'ı işgal etme girişimi ardından Adolf Hitler'in Alman ordularını Yunanistan'a doğru yönlendirmesiyle savaşın boyutu değişir ve İtalyanlar Almanya desteğiyle Yunanistan'ı işgal ederler. İşgal altında olunan süre boyunca Yunanistan halkı birçok zorluk ile karşı karşıya kalır. Ekonomi de tamamıyla çöker ve dışa bağımlı hale gelir. (Clogg, 1992, s. 178-179) Bu zaman diliminde çocukluk çağlarını yaşayan Raraou'nun komşusu "güzel" Afroditi'nin, imkânsızlıklar nedeniyle tedavi edilemeyen verem hastalığı yüzünden ölür. Çocuklar açlık nedeniyle koşamayıp oynamazlar. Yiyecek bulmak zorlaşıp yağmalar yaşanır. Bunlar o dönemdeki şartların ve temel insanı ihtiyaçları karşılamanın ne kadar ağır ve güç olduğunu gösteren örnekler olarak eserde yer alır.

Raraou'nun annesi Asimina'nın çocuklarının karnını doyurabilmek için bir İtalyan subayı olan Alfio ile seksüel birlikteliği büyük erkek kardeşin evi terk etmesine neden olur. Ailenin babasının savaştan dönmemesi, annenin yaşadığı evlilik dışı ilişki, büyük erkek kardeşin evi terk etmesi ve bunun yanında olumsuz hayat koşulları, savaş ve dönemin şartları nedeniyle parçalanan bir ailenin portresi çizilir. Böylece, Raraou'nun hayatındaki ilk acılı deneyimiyle karşılaşırız. Ancak Matesis, yarattığı bu yıkılan aile portresinin yanı sıra, özellikle kadınların ve sivillerin birbirleriyle olan ilişkilerinin ön plana çıktığı bir taşra hayatını tasvir eder. Yerel halkın bu işgal sürecine nasıl tepki verdiği hikâyenin bir eksenini oluşturturken, işgal sürecinde ortaya çıkan ve Yunanistan tarihinde önemli bir sivil oluşum olan direnişe, halkın ne ölçüde katıldığı ve nasıl tutumlar sergilediği bir diğer eksen olarak karşımıza çıkar. Hikâyenin ve eserde aktarılan direniş sürecinin ana karakterinden biri olan ve çalışkanlığı, duruşu ve vatansever kişiliğiyle öne çıkan

81939 yılında Metaksas, ikinci dünya savaşının arifesinde, Yunanistan'ı çatışmalardan uzak tutabilmek amacıyla İngiltere'ye karşı tarafsız bir politika izlemeye çalışır. Buna rağmen dönemin İtalyan lideri Mussolini ise müttefiki olan tek başına da zafer kazanarak Almanya'ya kendini kanıtlayabilmek endişesi içindedir. Bu nedenle dönemin Mussolini İtalyası, Yunanistan'ı hedef seçerek 1940 Ağustosunda Elli isimli bir yolcu gemisini denizaltıyla vurarak pek çok sivilin yaşamını yitirmesine sebep olur. 1940 yılının Ekim ayında ise İtalya'nın Yunanistan büyükelçisi Metaksas'a ültimatom verir ve İtalyan orduları Yunanistan'ın Arnavutluk sınırını geçer. Metaksas'ın bu ültimatoma verdiği ünlü "OXI (Ohi) / Hayır" cevabı ise Yunanistan'da mili bir coşku yaratsa da Almanya'nın desteğini arkasına alan İtalya, Yunanistanı işgal eder. Metaksas'ın "Hayır" cevabını verdiği tarih, günümüzde milliyetçi ruhu temsil eden ikonik bir gün olarak 28 Ekimde kutlanmaktadır. (Clogg, 1992, s.149 - 150) 
Bayan Kanello, bu durumu açıklarken kilit bir isim olarak düşünülebilir. Yerel halkın Kanello önderliğinde, işgal güçlerini bir şekilde yanıltarak dağdaki direniş̧̧ilere yardımları - örneğin; iç çamaşırlarında cephane taşımaları ya da ot toplamaya gider gibi davranarak işgalci güçlerin sıkı kontrollerini atlatmaları ve cephaneleri direnişçilere ulaştırmaları vb.- yaşanmış bir tarihin kurgulanarak aktarımıdır. Buna göre, eserde aktarılan olayların yaşanmış bir tarihin ürünü olduğu ya da en azından kurgu karakterler üzerinden anlatılan tarihsel bir süreç olduğu düşünülebilir. Bu unsurların yanı sıra, Bayan Kanello'nun hikâyesinde olduğu gibi eserde yer alan kurgusal karakterlerin kendi hikâyeleri diegesis bir anlatımı hypodigesis bir anlatıya dönüştürdüğü söylenebilir. Çerçeve hikâye, yan karakterlerin hikâyeleriyle birleşerek aynı nedende yani savaşın yarattığı ruhsal ve sosyolojik yıkıntı ekseninde birleşir. Böylelikle hikâye içinde hikâye olarak adlandırabileceğimiz anlatı tekniği; hikâyenin ana kurgusunu destekleyen bir unsur olarak karşımıza çıkar. Örneğin eserin ilerleyen saflarında, Raraou'nun babasının ölmediğini daha iyi şartlara sahip olacağını düşündüğü için dul bir kadınla evlendiğini ve bir önceki ailesini unuttuğunu öğreniyoruz. (Matesis, 2002, s. 211)

Raraou'nun babasının kendi hikâyesi, o dönem savaşın insanları ne kadar değiştirdiğini anlamamızda yazar tarafından sunulan yardımcı bir yan hikâye olarak düşünülebilir. Bu yan hikâyeler öykü içinde post modernist bir özellik olan temporal distortion yani geçiçi bükülmeler yaratır. Bu bükülmeler ve zaman açısından doğrusal olmayan anlatılar ${ }^{9}$ hem modernist hem de postmodernist eserlerde görülen yaygın bir tekniktir. Geçici bükülmeler genellikle ironi kullanılarak aktarılır. (Lewis, 2002, s. 124) Her ne kadar Dilsizin Kızı isimli eserdeki yan hikâyeler, ana hikâyede kronolojik bir çizgi izlese de ironik bir biçimde anlatılırlarken okuyucunun algısını ana karakterden yan karakterlere çekerek bir kırılma yaratır. Örneğin eserde, açlık yüzünden Bayan Salomi'nin papağanının yemek olarak sunulma hikâyesi ilginç bir örnek olarak karşımıza çıkar. Bununla beraber daha İtalyan asker Marcello'nun yan hikayesi, Raraou'nun babasının savaş bittikten sonra yaşadıkları ve tiyatro kumpanyasının gezerlerken gördükleri hem zamansal hem de mekânsal kırılmalar olarak eserde yer alırlar. Bu açıdan bakıldığında Matesis'in bu tekniği de başarılı bir şekilde kullanarak esere post modernist bir nitelik kazandırdığı söylenebilir.

İşal ve direniş süresince travmatik olduğu açıkça söylenebilecek olaylar yaşayan

9 Raraou'nun anlatısı kimi zaman geçmişi anlatırken zamansal bir bükülme yaratılarak, ana kahramanın içinde bulunduğu güncel döneme geçişler yapmaktadır. 
Raraou ve yerel halk, hemen ardından gelecek olan Yunan iç savaşının ${ }^{10}$ siyasi ve sosyal çalkantıları ve hayatın acımasız şartları içinde yaşam mücadelelerine devam etmektedirler. İç savaş sürecinden hemen önce ve işgalin sona ermesini takiben işgal güçleriyle işbirliği yaptığı iddia edilen yerel kimselerin yargısız infaz süreci Raraou ve özellikle annesi Asimina'yı derinden etkileyen ve hikâyeyi taşradan büyük şehre taşıyan bir "deneyime" sebep olur. Kitabın da başlığına esin kaynağı olan sahne ${ }^{11}$ Asimina'nın halka açık bir şekilde küçük düşürülmesi ve iş birlikçi olarak suçlanmasıdır. Bu olayın getirdiği yıkıcı etki ve baskılar nedeniyle ${ }^{12}$ annesiyle birlikte Atina'ya taşınmasıyla hikâye devam eder. Atina'da hiçbir sosyal yardım almadan iki bacağını bir kaza sonucu kaybetmiş bir sokak dilencisiyle beraber yaşarlar. Daha sonra Raraou, asıl mesleği doktorluk olan, ölmüş kişiler adına bile seçmen kaydı çıkartıp kendi lehinde oy kullandıran yozlaşmış bir politikacının koruması altında mütevazı evine ve maaşına kavuşur. Bu karakterin imajı 60'lardan itibaren Yunan siyasi tarihine karşı sembolik ve negatif bir anlam yüklediği düşünülebilir. Bu karakter siyaset sahnesinde rol olan bireylerin ne ölçüde yozlaşabileceğine ilişkin bir örnek olarak karşımıza çıkar. Ek olarak, yozlaşan sadece politika ve siyasi yaşam değildir. Tüm bu süreç zarfında toplum içinde de kültürel, sosyal ve ahlaki - hatta diniçöküntüler meydana gelmektedir. Örneğin, taşranın evli din adamının Almanlarla iş

10 Yunanistan İç Savaşı, 1946-1949 yılları arasında Yunanistan'ı siyasi istikrarsızlık içine iten, etkileri 1955 yılına kadar hissedilen ve temelde sağ-sol mücadelesi olan bir iç savaş olarak tanımlanabilir. Yunan yurtseverler II. Dünya Savaşı içinde Alman işgaline karşı çeşitli direniş örgütleri kurarlar. Bunlar arasında öne çıkan “Ulusal Kurtuluş Ordusu" (ELAS) sol, "Hür Demokratik Yunan Ordusu" (EDES) ise sağ eğilimlidir. Bu iki örgüt Alman işgal ordusuna karşı etkili bir mücadele içine girer. Stalin ile Churchill Alman yenilgisinden sonra Doğu Avrupa'nın durumunu Moskova'da görüşürlerken Churchill Yunanistan'ın Britanya etki bölgesi olarak kabul edilmesini önerir ve Stalin de bunu kabul eder. Yüzdeler Anlaşması olarak bilinen bu anlaşmadan hemen sonra, savaşın son yılında, Birleşik Krallık Yunanistan'a asker gönderir (C.M.Woodhouse, 2002, s. 237). Britanya ordusun ile birlikte ELAS ve EDES Yunanistan'ın Alman işgalinden kurtulmasında önemli bir rol oynar. Ancak işgalin sonlanmasından sonra Yunanistan'a beklenen barış ve huzuru gelmez ve ülke beş yıl sürecek olan son derece kanlı ve yıkıcı bir iç savaşın içine girer. ELAS olarak bilinen oluşum bu kez mevcut Britanya destekli hükümete ve sağ görüşlü EDES ile çatışmaya girecek ve bir iç savaş süreci başlamış olacaktır. Bu iç savaş, Yunanistan tarihinde, bir anlamda komünizmin önüne geçmek için dış güçler tarafından desteklenen $\varepsilon \mu \varphi u ́ \lambda ı$ (emfilio) yani kardeş kavgası olarak bilinmektedir.

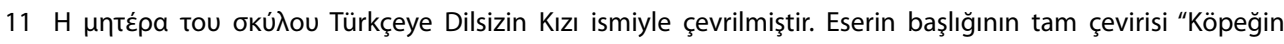
Annesi" olarak yapılır. Köpek anlamına gelen " $\Sigma$ KU í (Skili)" aynı zamanda halk dilinde fahişe anlamına gelir. Yaşadığı topluluk önünde aşağılanma olayından sonra Asimina konuşma yetisini bilinçli olarak kullanmaz. Bu nedenle dilsiz olarak tanımlanır. Kitabın çevirmeni de bu nedenle bu başlığı uygun görmüş olmalıdır.

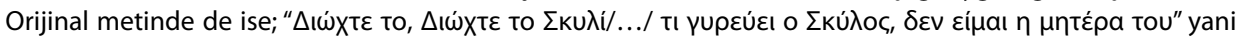
[çev. "Atın bunu, atın bu köpeği... Ne aranıyor bu köpek, ben annesi değilin onun.] şeklinde Asima'nin söylediği sözler, orijinal metinin başlığını oluşturmuştur.

12 Raraou ve ailesinin gördüğü sosyal baskı, bir anlamda cadı avı, dayanılmaz boyutlara ulaşır. Her ne kadar yakın komşuları sosyal baskıyı bertaraf etmeye çalışsalar da bu durum Raraou ve annesinin Atina'ya göç etme planlarını değiş̧irmez. Üstelik Raraou durumu Atina'da "Şimdiki durumumuz işgal dönemi dediğimiz günlerdekinden daha kötüydü" diye açıklayacaktır. (Matesis, 2002, s. 135) 
birliği yapan fahişe ile ilişkisi, Bayan Ksirudi karakterinin kızlarının önce İtalyanlar sonra Almanlarla gönül eğlendirmesini desteklemesi ve işgal bittikten sonra müttefik güçlerin ve direniş̧̧ilerin yanında yer alması gibi durumlar hem ironik hem de trajik ikilemler olarak karşımıza çıkar. Buna benzer ikilemler, Raraou'nun anlatısı aracılığıyla eserin tümüne yayılmıştır. Raraou, tiyatro kumpanyalarında ülkenin küçük taşralarını gezmeye devam eder ve geçmişinden tanıdığı insanlarla bu gezilerinde zaman zaman karşılaşarak savaşın ve dönem koşullarının insanları nasıl değiştirdiğini ve bunun günümüze nasıl yansıdığını anlatır.

Raraou karakterinin de kendisini hikâyenin başında bir aktris olarak okuyucuya tanıtması, Matesis'in tiyatro geçmişi göz önüne alındığında, yazar ve yarattığı kahraman arasında şaşırtıcı olmayan bir ortaklık olarak karşımıza çıkar. Tiyatro sanatına ve "Toska" gibi tiyatro tarihinin önemli eserlerine referanslar oldukça açık bir biçimde romanda yer alır. Öte yandan, yazarın kullandığı özgönderimsel anlatı, anlatıcıların romanın farklı bölümlerinde değişmesi ve olay örgüsündeki episodik ve çağrışımlı anlatılar okuyucuya tiyatro sahnesini anımsatabilir. Yazarın tiyatro geçmişi ve hayat kavramını sorgulamak gibi dönemin eğilimleri göz önünde bulundurulduğunda, tiyatro ve absürdün edebiyata etkisi Matesis'in bu eserinde oldukça açık bir biçimde görülebilir. Bu noktada, tiyatroya yapılan göndermeler post modernist bir nitelik olan pastiche unsurunu hatırlatabilir. Mchale, (1978, s. 66), Giannina Braschi'nin şiir, reklam ve dramayı karıştırmasını örnek vererek, pastiche unsrunu; metinlerarasılılıkla ilişkili olarak, pek çok unsuru karıştırmak ve ya "yapıştırmak" olarak niteler. Pastiche, kaotik ve çoğunlukçu postmodern toplumun bir yansıması olabileceği gibi aynı zamanda benzersiz bir anlatı yaratmak için birden fazla türün birleştirilmesidir. Matesis, Raraou'nun adeta tiyatro seyircisine anlatıyormuş hissi veren hikâyesi üzerinden tiyatro eserlerine, gezici tiyatroların işleyişine ve doğal olarak tiyatro oyuncularının birbirleri ve seyircileriyle ilişkilerini aktarır. Doğal olarak, işgal, savaş ve direniş ve hemen ardından gelen iç savaşın tiyatro sanatına ve sanatçılarına ne ölçüde etki ettiği de gösterilir. Örneğin; Raraou'nun sanat hayatına atılmasına öncülük eden Bayan Salomi dağlarda direnişçilere sergiledikleri bir oyun sırasında açlık nedeniyle bayılır. (Matesis, 2002, s. 115) Tiyatro kumpanyaları, köyden köye yolculukları sırasında bir çocuğun annesinin cesedini el arabasında taşımasına ve Almanların direniş̧̧ilere misilleme olsun diye masum insanları asarak öldürmesi gibi savaşın çirkinliğini ve yıkıcılığını gösteren olaylara da tanıklık eder. (Matesis, 2002, s. 116) 


\section{Postmodern Bir Kahraman: Raraou}

Raraou hem solcu şarkıları sevip hem de sağcı ideolojiye sahip olduğunu sıklıkla dile getiren (Matesis, 2002, s. 2) bir karakter olarak karşımıza çıkar. Ancak daha sonra bu kendi içinde çelişen görüşlerin nedenini Raraou, yine kendi ağzından açıklar ${ }^{13}$. Ruhu solcular ve direnişçilerden yana da olsa, hayatını devam ettirebilmesi için gerekli maddi kaynağı ona devlet vermektedir. Devletten aldığı mütevazı maaşını kaybetmek istememektedir. Bu nedenle babasının ortaya çıkması Raraou'da ufak bir gerginlik yaratır ancak babasının ölüm haberi onu rahatlatır. (Matesis, 2002, s. 215) Aynı şekilde işgal döneminde direnişçilere dağda yardım eden Kanello'yu karakola ihbar eden kişiyi bildiğini fakat o kişinin milletvekili olmasından dolayı ismini vermeyeceğini yoksa maaşını kaybedeceğinden korkar. Dönemin yönetimde hâkim güçlerini sorgulamadan destekler gibi gözükmesi bu sebeple olabilir ${ }^{14}$. Bunun yanı sıra Raraou, kendisini fettan, seksüel olarak aktif ve başarılı bir tiyatro sanatçısı olarak sunar. Ancak, anlatımı zenginleştiren bir psikiyatri raporu bunun aksini bildirir. Raraou'nun bakire ve akli dengesi yerinde olmayan zararsız bir kimse olduğunu açıklayan bu rapor aslında ana kahramanın tutarsız yapısını ve hasarlı benliğinin okuyucuya sunulan göstergesidir. Bu noktada, yakın dönem Yunan tarihinin gerçek olayları ve öte yandan hayatın sunduğu acımasız şartlar Raraou'nun dengesiz yapısının ana nedenleri olarak sunulur.

Tüm bunlar göz önüne alındığında, Raraou karakterinin kendi içindeki ikilemleri ${ }^{15}$, sosyal ve politik yapıya karşı tutumu, insanlarla kurduğu ilişkiler göz önüne alındığında Matesis'in Raraou'yu bir anti kahraman ${ }^{16}$ olarak yarattığı düşünülebilir. Kızılçelik (1996, s. 36), postmodern romanın tanımını yaparken; romanın tüm ideolojik felsefelere karşı olduğunu, iki kutuplu bir ortamda kalarak gelenek ile modern ya da sağ ile sol gibi kavramların arasında gidip geldiğini ve buna rağmen geçmiş ve gelecekler bağlarını koparmadığını, evrensel bütünlük yerine çoğulcu

13 Matesis, 2002, s. 82 [çev. “... fakat gemimi yüzdürebilmek amacıyla bir ömür boyu yaptığım gibi, gönül okşamam gerekiyordu."]

141950 -1974 arası olarak tanımlanan bu dönem, iç savaşın ardından ortaya çıkan siyasi karışıklıkları ve sosyal çalkantıları içinde barındırır. İç savaşın İngiltere gibi dış güçler tarafından desteklenmesinin ardından yönetimde sağ ideolojinin hâkimiyetinin söz konusu olduğu dönemdir. bknz. (Clogg, 2002, s. 177- 202)

15 Eserin ilerleyen bölümlerinde ana karakterin psikolojik durumu hakkında bilgiye okuyucular, bir psikiyatri raporu üzerinden ulaşmaktadır. (Matesis, 2002, s. 206-207)

16 Anti-kahraman; edebiyat ve sinema başta olmak üzere günümüzün popüler kültüründe idealleri, amaçları ve kişiliği alışılageldik kahramanların tam zıddı olan başkarakterleri tanımlamak için kullanılan post modern bir kavramdır. 
yani maximalist bir tutum edindiğini ifade eder. Bu açıdan bakıldığında romanın ana kahramanı da postmodernist bu ilkeleri üzerinde taşır. Geçmiş ve gelecek arasında gidip gelmeler yaşar, ideolojik görüşlerin hepsine karşı çıkar ancak iki farklı ideoloji arasında kalarak dengesiz bir yapıyı yansıtır. Özellikle ideolojik karmaşık ve çelişkiler postmodern bir kahraman için gerekli unsurlardır. (Şevki, 2009, s. 96-99) Ayrıca postmodern roman kahramanlarının kaygısı vazgeçilmez mutlak değerleri savunmak ya da evrensel insanın göstergesi olmak değildir. Bu tür romanlardaki kahraman küçük bir topluluğun ya da bir azınlığın bir örneği ya da kendisidir (Kafaoğlu - Büke, 2011, s. 223). Raraou da aynı bu biçimde, Yunan kenar mahalle kültürünün bir temsilcisidir. Sadece kendini anlatır ve kutsal sayılabilecek ulus, vatan vb. kavramların doğruluğu sorgularken mutlak gerçeği aramaz ama kendi çıkarlarını temel değerlerin üzerinde tutar. Bu özelliğiyle de Raraou, postmodernist bir anti kahraman olarak karşımıza çıkar.

\section{Dilsizin Kızı ve Milliyetçilik}

Anastasiadis ${ }^{17}$; çağdaş Yunan romanında, işgal-direniş-iç savaş döneminin bir ana başlık olmaya devam ettiğini ve bu travmatik deneyimin, yazarları yaratıcı anlatı teknikleri üretmeye ve yeniden sunum stratejileri belirlemeye ittiğini belirtir. Anastasiadis'e göre bu tür romanlarda anlatı; yönetici devlet organlarının, işgalcilerin ve işbirlikçilerin aynı zamanda direnişçilerin ve solcu aktivistlerin baskısını aktarır. Bunun yanı sıra anlatıcı, elverişsiz ve rahatsı edici geçmişin manifesto haline geldiği farklı belirtileri tasvir ederler. Anlatıcl; geçmişe dönüşlerden, kâbuslardan ve uykusuzluktan, eski olayları yeniden yaşama eğiliminden, hikâye uydurmadan ve hatta şiddet eğilimlerinden mustariptir. Anastasiadis'in sözüne ettiği gibi Raraou, kimi zaman sürreal rüyalar görür, kimi zaman ise Atina'da annesiyle berbaber yaşadıkları oda arkadaşı sakata - her ne kadar kendilerini ondan korumak için olsa da- şiddet gösterir. Kendini oldukça başarılı ve femme fatale bir tiyatrocu olarak tanıtır. Raraou'nun psikolojik yapısını aktaran bu Anastasiadis'in görüşünü destekler niteliktedir. Matesis ise bu unsurların nedenini, İkinci Dünya Savaşının savaşın getirdiği yıkımla, işgal ve direnişin getirdiği acımasız şartlarla, kıtlık döneminin

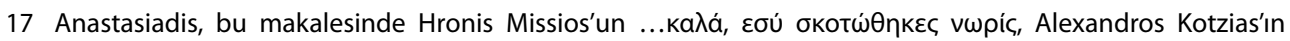

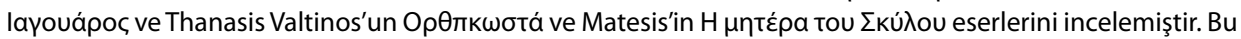
dört eserin ortak noktasının biçimsel olarak anlatı ve tarihi gerçeklerin insanlar üzerinde yarattığı travmatik etki olduğunu ifade eder. Athanasios A. (2011) "Trauma - memory - narration: Greek Civil War novels of the 1980s and 1990s" , Byzantine and Modern Greek Studies Vol. 35 No. 1 (2011) s. 92-108. Centre for Byzantine, Ottoman and Modern Greek Studies: University of Birmingham 
yarattığı travmalarla ve hemen ardından aynı toplumun insanlarının ideolojik ve dış güçlerin desteğiyle birbirlerini öldürdükleri iç savaş ortamıyla ilişkilendirir.

Dilsizin Kızı, genel olarak incelendiğinde gerek Raraou'nun anlatısı gerekse hikâyede yer alan karakterlerin söylemleri, romanın kısmen anti milliyetçi bir söyleme sahip olduğunu düşündürebilir. Bu söylem, gündelik hayatın çaresizliği içinden aktarılır. Raraou ve ailesi işgal döneminde, yoksulluk ve çaresizlik nedeniyle Yunan bayrağını sökerek iç çamaşırı olarak kullanırlar. Bu gören taşranın papazı önce tepki gösterse de anne Asimina ile konuşunca ona hak verir. Bayrağı bir ulusun simgesi olarak nitelendirdiğimizde ve Kalaycı́nın Birikim dergisinde yayınladığı (1998) makalesindeki görüşü ${ }^{18}$ göz önünde buldurduğumuzda, savaş koşullarında ve dönemin şartları altında bayrağın bir değeri olmadığı sembolik olarak vurgulanmaktadır. Raraou'nun annesi Asimina ilişkisi olduğu İtalyan Alfio'nun Epalksis'i terk ettiği zaman, onun işgal döneminde çocukları ve kendisi için gıda temin etmesi nedeniyle yazdığı minnet mektubunda ulus kavramını anlamlandıramadığını ifade eder ${ }^{19}$. Bu durum iki boyutta yorumlanabilir. Birincisi; sıradan insanların ulus kavramını tam olarak anlayamadıklarıdır. Bunun nedeni ise; sıradan ve taşra insanının, dönemin ağır şartları altında var olma mücadelesi vermeleridir ve hayatı anlamaya çalışırken ulus, ikinci plana itilen soyut bir kavram olur. Diğeri ise; Alfio'nun her ne kadar karşılıksız olmasa da Raraou ve ailesine yaptığı yardımlar nedeniyle insani değerlerin ulus kavramından daha güçlü bir etkiye sahip olması ve insani davranışın ulus kavramının önüne geçmesidir. İki boyutta ulus, devlet, vatan gibi kavramların değerini dönemin şartları altında okuyucuya sorgulatmaya yönelik bir adım olarak algılanabilir. Buna ek olarak; Raraou da anlatısında annesi ve Alfio arasındaki ilişki ile vatan kavramını karşılaştııı. Bu karşılaştırma insani değerlerin vatan gibi kavramlardan daha somut bir etkisi olduğu izlenimi uyandırabilir ${ }^{20}$.

18 Kalaycı görüşünü makalesinde; "Bayrak için her şeyden önce bir sahip oluşu imlediği söylenebilir, hattâ yalnızca sahip oluşu değil, ait oluşu da imlemektedir; bir ulusal kimliğe ya da bir devlete sahip ve ait oluşu. Sahip oluşu hem meşrulaştıran hem de belgeleştiren bir göstergedir bayrak. Söz konusu ülke olduğunda, sahip olunan toprak üzerindeki mülkiyet hakkını gösteren bir tapudur." Şeklinde ifade eder. Kalaycı, H. (1998). Bayrak, Milliyetçilik, Kutsallık ve Postmodern Durum. http://www.birikimdergisi.com/birikim-yazi/6276/bayrakmilliyetcilik-kutsallik\#.WJ4i4vmLREZ

19 Matesis, 2002, s. 33 [çev. "Ulusumuzun düşmanısınız gerçi, ama sizi de bekleyen bir anacığınız var, bunu iyi biliyorum; ama şu ulus denen nasıl bir halt olduğunu nasıl bir halt olduğunu ne biliyor ne de anlıyorum; neyse, sizinki de bir ulus işte. Hayır dualarımla gidiniz."]

20 Matesis, 2002, s. 66 [çev. "[...] Yurt için hangi değerler yüceydi? Bütün bunların sonucu nereye varacaktı? Yurt soyut bir kavramdı. Fakat Bay Alfio, etten kemikten, somut bir varlıktı, evimiz de somuttu. Peki ya Vatan?"] 
Temel olarak eserde, insanın doğası ve dönem koşullarının insanlar üzerindeki somut etkisi, ulus, vatan, devlet gibi soyut kavramların önüne geçmektedir. Dönemin şartları nedeniyle insanların yaşadığı hayatın acımasızlığı ve bir anlamda varoluşsal mücadelenin eserdeki karakterlerin ulus anlayışının önüne geçtiği söylenebilir. Bu hem ironik hem de trajik anlatılarla desteklenir. Böylece Raraou için vatan, ulus, bayrak gibi kavramların toplum içinde bir yozlaşmaya uğradığı, yaşanılan olayların etkisiyle bazı kavramların temel anlamları dışında farklı anlamlar ifade ettiği ya da bir anlam ifade etmediği düşünülebilir. Bununla birlikte Raraou özellikle milliyetçilik, vatan ve ulus gibi kavramları sorgularken gerek kendisi doğrudan soru yönelterek gerekse bir başkasının hikâyesini anlatırken ortaya çıkan soruları aktararak okuyucuyu da bu kavramları sorgulamaya yönlendirir. Bu durumu post modernist bir nitelik olan "participation" yani katılma ile ilişkilendirmek mümkündür. Post modern yazarlar okuyucuyu yazardan ve öyküden ayrı tutan modernist eserlerin aksine soru sorma, sorgulamayı ya da anlatının tamamlanma sürecini okuyucuya bırakma gibi eğilimler gösterdikleri için Matesis de, Raraou karakteri üzerinden okuyucuyu hikâyeye katarak post modernist bir nitelik kazandırır.

\section{6. “Öteki”}

Söz konusu roman Çağdaş Yunan Edebiyatı́nın bir parçası olduğu için ister istemez Matesis'in Dilsizin Kızı eserinde "öteki" kavramı incelemek gereklidir. 1945 sonrası eser veren yazarların politik görüşleri "öteki" kavramını doğrudan etkiler ${ }^{21}$. Matesis'in bu eserinde "öteki" doğrudan Türk değildir. Buna rağmen işgal döneminde yeni doğum yapan ancak Kızılhaç'ın yapacağı yiyecek yardımını kaçırmamak için dışarı çıkmaya hazırlanan Bayan Kanello'nun annesinin, kızına "Türklere yaraşır bir biçimde" (Matesis, 2002, s. 26) çıkışması, bir başka değişle despot ve sert bir üslupla söylenmesi, bir Türk stereotipi olarak karşımıza çıkar22. "Öteki" ile ilgili olarak vurgulanması gereken bir başka olgu ise; bir tiyatro oyunu sırasında Türk askerini canlandıran oyuncunun Alman SS üniformasıyla sahneye çıkmasıdır. (Matesis, 2002, s. 116) Türk askeri rolündeki oyuncunun Alman üniformasıyla sahnede yer alması

21 Demirözü; 1945 sonrası düzyazımı ile ilgili olarak, sol görüşlü yazarlar için milli "ötekinin Türk/Ermeni/Yahudi olmadığını ve sınıfsal bir yaklaşımla yorumladıklarını belirtir. Sağ görüşlü yazarlar içinse Yunan olmayan herkesin "öteki" olduğunu ve Türklerin de "tarihsel öteki" olarak karşımıza çıktığını ekler (Demirözü, 2015, s. 186 - 187).

22 Millas, 2000, s. 331. Bu bölümde Millas, tarih içindeki rolü nedeniyle, yönetici Türk'ün Yunan romanındaki imajııın baskıcı yani despot olduğunu ifade eder. Kanello'nun annesinin baskıcı tavrı, edebiyattaki yönetici Türk imajını hatırlatabilir. 
tarihsel bir bağdaştırma bir başka değişle Türk "öteki" üzerinden Alman "ötekine" referans olarak yorumlanabilir. Bu sahnede, Yunan ailelerinin Osmanlı yönetimi altındayken yaşadığı devşirme sistemi, tarihsel bir atıf olarak karşımıza çıkar. 1945 sonrası eserler genel olarak düşünüldüğünde, Yunanların yaşadığı tarihi olaylar pek çok eserde okuyucuya hatırlatııı. (Demirözü, 2015, s. 187) Matesis de eserinde, 1945 sonrası yazarlarında görülen bu hatırlatmaya benzer bir şekilde tarihi Türk "ötekini" hem hatırlatır hem de Alman işgali ile bir bağıntı kurar. Bunun nedeni de iki ulusun da Yunan toprakları üzerinde kısa ya da uzun süreli bir egemenlik sağlamış olmasıdır.

Bu unsurlara rağmen, eserdeki "öteki" işgalci Almanlar ve İtalyanlardır. Almanlar ya da işgalci Almanlar, eserde doğrudan olumsuz bir "öteki" imajı çizerken, İtalyanlar kısmen olumlu "öteki"lerdir. Almanlar, öncelikle "işgalci" konumunda olduklarından hali hazırda olumsuz bir imaj çizmektedir. Ancak, Raraou'nun anlatısı üzerinden askerlerin görevden kaçarak -üstü kapalı bir biçimde verilse de- fiili livata yapması (Matesis, 2002, s. 29) ve Almanların yenilgisi sonrasında etraftaki köyleri yakıp yıkmaları ve yerel halkı acımasızca infaz etmeleri (Matesis, 2002, s. 132) gibi anlatılarla desteklenir. Tüm bu örneklerin yanı sıra, Alman ordularının yerel halka karşı gösterdiği acımasız ve haksı tutum olumsuz imajın oluşmasında temel unsur olarak ortaya çıkar. Özellikle, tüm yerel halkın da şahit olduğu, insanlar açlık ve yetersiz beslenme nedeniyle oldukça trajik bir süreç yaşarlarken, birkaç patates için Raraou'nun kardeşi Fani'nin eline Alman askeri tarafından tüfek ile vurulması ve Fani'nin elinin sakat bırakılması olayı (Matesis, 2002, s. 51-54) okuyucunun algısında Alman imajına karşı negatif bir tutum oluşturur. Bu sahnede, Bayan Kanello'nun Alman askerlerine karşı duruşu ve Fani'yi onların elinden kurtarması bir kahramanlık örneği olarak görülebilir. Öte yandan, Raraou'nun annesi Asimina'nın kıtlık döneminde çocuklarının gıda ihtiyacını karşılayabilmek adına beraber olduğu İtalyan Komutan Alfio'ya yazdığı mektupta, ondan övgüyle söz eder. Yunanca öğrenip tiyatro kumpanyasına katılan ve Almanların kendisini Rus cephesine göndermek istemesi üzerine askerden kaçan Italyan Marçello'nun hikâyesi de okuyucunun algısında her ne kadar işgalci konumunda olsalar da İtalyan "öteki" için olumlu bir imaj oluşturabilir. Böylece; Italyanların daha insani ancak Almanların tamamıla insanlık dışı ve acımasız eylemleri öteki imajını yaratan önemli iki farklı nokta olarak karşımıza çıkar. Hem Italyanlar hem de Almanlar işgalci konumundayken, Almanlara kıyasla İtalyan karakterlerin insani yanının öne çıkartılması İtalyan işgalciler için kısmen olumlu imaj yaratma eğilimi olduğu söylenebilir. Bir başka deyişle "olumlu" işgalciler İtalyanlar, "olumsuz" işgalciler ise Almanlardır. 


\section{Sonuç}

"Öteki" kavramı ise Matesis'in bu eserinde kendisinden önce gelen 45 Kuşağı yazarların eğilimini devam ettirir. Tarihsel "öteki" Türk bir stereotip olarak karımıza çıkar. Ancak, "öteki" olarak sunulan Almanlar ve İtalyanlar iki farklı eksende okuyucuya sunulur. Bu açıdan bakıldığında yaşanan tarihsel olayların "öteki"nin kimliğini değiştirdiğini ancak toplumsal hafızanın tarihsel "öteki"yi hemen bırakmadığı görülebilir. Tarihsel öteki "yeni öteki"yi hem karşılaştırmak hem de hikâyeyi desteklemek amacıyla kullanılan önemli bir araç olarak karşımıza çıkmaktadır. Eserin, ilk basım tarihinden (1990) günümüze kadar güncel kalmayı başardığı rahatlıkla söylenebilir. 45 Sonrası kuşağı yazarları arasında sınıflandırılabileceğimiz Matesis, bu eserinde, tarihi olayları tasvir etme ve bu olaylardan çarpıcı bir şekilde etkilenen karakterler yaratma konusunda oldukça rahat bir şekilde hareket etmektedir. Tiyatro geçmişini, düz yazıda gerek metin içindeki göndermeler gerekse üslup açısından sunan Matesis, ait olduğu 45 Kuşağı Çağdaş Yunan Edebiyatının ve Dünya Edebiyatının eğilimlerini bu eserinde oldukça net bir şekilde yansıtır. Bu açıdan bakıldığında Batı kanonunda çoktan yerini almış Çağdaş Yunan Edebiyatının önemli bir ismi olarak nitelendirilebilir. Ayrıca, yazarı sadece tiyatro eserleri veren bir yazar olarak nitelendirmenin oldukça haksız bir sınıflandırma olacağı, roman yazarı olarak da oldukça etkileyici bir eser verdiği açıkça söylenebilir. Eserin çok sesli ve çok karakterli yapısı hikâyeyi güçlendirdiği gibi tarih sahnesinde yaşayan olaylardan, herhangi bir ideoloji gözetmeksizin, tüm insanların etkilendiğini Raraou'nun naif anlatısıla aktarmaktadır. İnsani insan yapan özelliklerin hayat kavramıla nasıl şekillendiği ve tarihi olayların bu süreçteki etkisi, trajikomik bir anlatıyla desteklenirken insanların varoluşsal ikilemleri ve yozlaşan yüzlerini çarpıcı bir biçimde aktarılır. Bu anlatı aslında çok daha derin mesajlar içermektedir. Okuyucuya milliyetçilik, ulus, vatan gibi kavramları sorgulatmayı ve hayatın yıkıcı gerçekleri ve absürtlüğü içinde insani değerlerin önemini hatırlatır. Postmodernist romanının pek çok niteliğini de içeren Pavlos Matesis'in Dilsizin Kızı Çağdaş Yunan Edebiyatının Yunan geleneğini ile batı edebiyatında görülen eğilimleri birleştirerek hem kendine has yapısını korumuş hem de batı kanonundaki yerinin haklı olduğunu göstermiştir. Çünkü Matesis, bu eserinde gerek karakterler gerekse olay örgüsü açısından toplumsal ve insanı kavramları ve perspektifleri sorunsallaştırarak bunların sorgulanmasına ve hatta yadsınmasına olanak sağlar. Bu olanağı da postmodernist romanın niteliklerini kendi üslubunda kullanarak yaratır. Bu bağlamda; mevcut sorunların nedenini geçmişte yaşanan işgale direniş, açlık ve iç savaş süreçlerinin bir sonucu olduğu düşüncesi anti 
kahraman olarak nitelendirilebilecek Raraou'nun anlatısı içinde okuyucunun değerlendirilmesine bırakılır. Buna rağmen Pavlos Matesis'in bu eseri ve diğer eserleriyle birlikte akademik çalışmalara konu olması, bununla birlikte yazar ve eserleri üzerinde daha ayrıntılı ve incelikli çalışmalar yapılması gerektiği açıktır.

\section{Kaynakça}

Athanasios A. (2011). Trauma - memory - narration: Greek Civil War novels of the 1980s and 1990s. Byzantine and Modern Greek Studies 35(1), 92-108.

Beaton, R. (2004). An introduction to modern Greek literature. Oxford: Clarendon.

Clogg, R. (1997). Modern Yunanistan tarihi (D. Şendil, Çev.). İstanbul: İletişim.

Demirözü, D. (2015). İşgal, direniş, iç savaş: Yunan Edebiyatında II. Dünya Savaşı Yılları, İstanbul: İstos Yayın.

Dimaras, C. Th. (1972). A history of modern Greek literature ( $1^{\text {st }}$ ed.). New York: State University of New York Press.

Dujardin E. (1925). Les lauriers sont coupés. Paris: Messein.

Eco, U. (1994) Reflections on the name of the rose (W. Weaver, Trans.). London: Minerva.

Faulker, W. (2015). Döşeğimde ölürken (M. Belge, Çev.). İstanbul: İletişim.

Gassner, J., \& Quinn, E. (Eds.). (2002). The reader's encyclopedia of world drama. New York: Thomas Y. Crowell.

Matesis, P. (n.d.). In Biblionet. Retrieved May 25, 2017: http://www.biblionet.gr/author/12455/\%CE\%A0\%CE\% B1\%CF\%8D\%CE\%BB\%CE\%BF\%CF\%82_\%CE\%9C\%CE\%AC\%CF\%84\%CE\% B5\%CF\%83\%CE\%B9\%CF\%82

Hutcheon, L. (2010). A poetics of postmodernism: History, theory, fiction. New York: Routledge.

Hutcheon, L., \& Valdés J.M. (1998). Irony, nostalgia, and the postmodern: A dialogue. Poligrafías. Revista de Literatura Comparada, 1998-2000(3), 18-41.

Kalaycı, H. (2017). Bayrak, milliyetçilik, kutsallık ve postmodern durum. Birikim Dergisi, (Ocak-Şubat 1998), 105106. Retrieved from http://www.birikimdergisi.com/birikim-yazi/6276/bayrak-milliyetcilik-kutsallik\#. Wi45gVV190z

Kesselring, J. (1942). Arsenic and old lace. New York: Dramatist Play Service.

Kızılçelik, S. (1996). Postmodernizm dedikleri. İstanbul: Saray Kitabevleri.

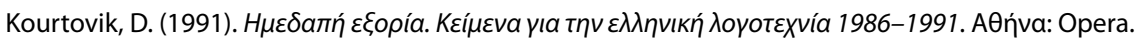

Lewis, Barry (2002). Postmodernism and literature. In S. Sim (Ed.), The Routledge Companion to Postmodernism (pp. 3-14). NY: Routledge.

Lyotard, J. (1990). Postmodern durum: Postmodernizm (A. Çiğdem, Çev.). İstanbul: Ara Yayıncılık.

Matesis, P (2000). Dilsizin kızı (S. Aycan, Çev.). İstanbul: Everest Yayınları.

McCaffery, L. (1986) Postmodern fiction: A Bio-bibliographical Guide. Wesport, Connecticut: Greenwood Press.

McHale, B. (1987) Postmodernist fiction. London: Methuen.

McHale, B. (1992). Constructing postmodernism. London: Routledge.

Millas, H. (2000). Türk romanı ve "öteki": Ulusal kimlikte Yunan imajı. İstanbul: Sabancı Üniversitesi.

Moran, B. (1990) Türk romanına elestirel bir bakış 2: Sabahattin Ali'den Yusuf Atılgan'a. İstanbul: İletisim Yayınları. 
Nicol, B. (2009). Postmodern fiction: Theory and practice. In The Cambridge Introduction to Postmodern Fiction (pp. 17-49). Cambridge: Cambridge University Press.

Politis, L. (1973). A history of Modern Greek Literature. Oxford: Oxford University Press.

Sharma R. ve Dr. Chaudhary P. (2011) Common themes and techniques of postmodern literature of Shakespeare. International Journal of Educational Planning \& Administration, 1(2), 189-198.

Şevki, A. (2009). Edebiyat ve Yorum. Ankara: Havuz Yayınları.

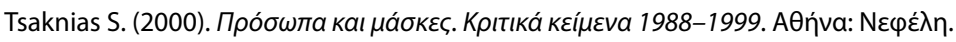

Tziovas, D. (2003). The other self: selfhood and society in modern Greek fiction. Lanham, MD: Lexington Books.

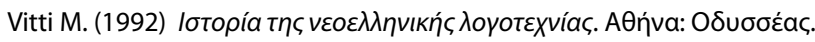

Woodhouse C.M. (2002). The struggle for Greece 1941-1949. London: Hurst \& Company.

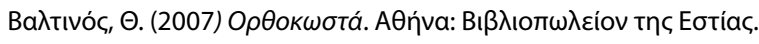

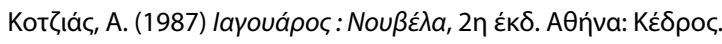

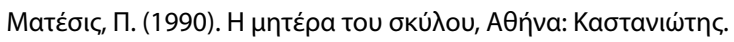

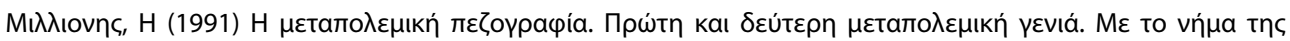

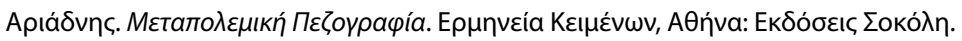

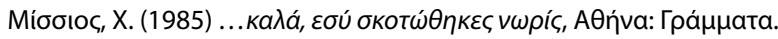

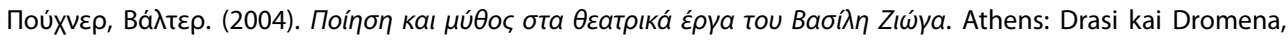
Polytropon.

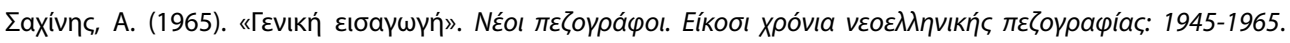

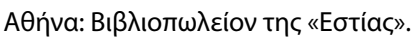


